\title{
Adult T-cell leukemia/lymphoma
}

INSERM

\section{Source}

INSERM. (1999). Orphanet: an online rare disease and orphan drug data base. Adult T-cell leukemia/lymphoma. ORPHA:86875

\#946;. Presentation is heterogeneous and is typically of aggressive leukemia or lymphoma, variable skin eruptions, and visceral organ involvement. 